\title{
Using Mind Mapping in Social Studies at Public Junior High School No.1 South Siberut Mentawai
}

\author{
$1^{\text {st }}$ Dessy Amelia \\ Student of Dep. of History Education, \\ Faculty of Social Studies, \\ Universitas Negeri Padang, Padang, Indonesia \\ dessy.ameli3192@gmail.com \\ $2^{\text {nd }}$ Buchari Nurdin* \\ Lecturer of Dep. of History Education, \\ Faculty of Social Studies, Universitas Negeri \\ Padang, Padang, Indonesia
}

\author{
$3^{\text {rd }}$ Siti Fatimah \\ Lecturer of Dep. of History Education, \\ Faculty of Social Studies, Universitas Negeri \\ Padang, Padang, Indonesia

\begin{abstract}
$4^{\text {th }}$ Aisiah
Lecturer of Dep. of Historical Education, Faculty of Social Studies, Universitas Negeri

Padang, Padang, Indonesia
\end{abstract}

grade VIII of Public junior high school No. 1 South Siberut Mentawai by using mind mapping. Social studies learning process became more interesting and students enthusiast in learning. The research result shows that the student's mind mapping learning media innovation is still very simple and the teachers in schools are not accustomed to use of learning media because the learning process is conventional.

\section{Keywords-Mind Mapping Learning Media, IPS}

\section{INTRODUCTION}

In the era of globalization, the development of increasingly modern science and technology must be balanced by the ability of the quality of human resources who must also be competent and follows the ITC development. This must be a serious concern, if there is no match between the quality of human resources and balanced technology, then that will be a big problem. Increasing the quality of qualified human resources can be realized through created learning media. 
Education is a conscious or planned effort to create an atmosphere of learning process. The students actively develop their capability to have spiritual strength, moral intelligence, self-control, personality, and the skills needed by the community and nation state. Education is the people awareness through systematic effort directed by the responsebility to influence students to have the traits in accordance with the goals of education. [1] states that education should be able to codify and provide encouragement to optimize and awaken students' potential creativity in the learning process [2]. [3] state that education in Indonesia based on the National Education Law is divided into several levels, namely: primary schools, junior high schools senior high schools and higher education.

Through the social studies learning process in junior high school, it is expected that students will be able to reach the level of thinking formally. Social studies is part of the school curriculum of which the main responsibility is to help students develop knowledge, skills, attitudes, values needed to participate in community life at the local, national and global level. In line with the goals of the 2004 social studies curriculum [4], which is examine a set of facts, events and concepts and generalizations related to human behavior to build themselves, their communities and environment based on past experiences that can be interpreted for the present and anticipated for the future [5]. Social studies are one of the subject given at primary school level. Social studies examine a set of events, facts, concepts, and generalizations related to social issues.

According to [6], learning media are tool in the learning process both inside and outside of the many grade level classrooms. Learning media become one of component learning resources containing instructional material that can stimulate the students to learn. Learning media plays an important role in communication process in teaching and learning. According to [7], learning media are everything that is used to channel messages and can stimulate thoughts, feelings, attention and learning abilities. Learning media encourage the occurrence of learning processes that are intentional, purposeful and controlled. The basis for developing learning media according to [8] is as follows; (1) philosophical foundation; (2) psychological foundation; (3) technological foundation; (4) empirical foundation.

[9] states that "learning media is a vehicle for channeling messages or information in learning". According to Seels and Glasgow in [10] media grouping viewed in terms of technological development consists of traditional media grouped into projected stationary visuals, for example opaque projections (invisibility), overhead projections, slides and filmstrips. Non-projected visuals for example pictures, posters, photos, charts, graphs, diagrams, exhibits, info boards and feathers, audio for example recordings of discs, tapes, reels and cartridges. Multimedia presentations for example slides plus sound and multi images, projected dynamic visuals, such as film, television and radio. Printed media for example text books, modules, programmed text, workbooks, scientific magazines, periodicals, hand-outs. Media games such as puzzles, simulations and board games reality for example models, specimens (examples) and manipulative.

For this reason, the media developed in this research is mind mapping. By using mind mapping as a learning medium, students are expected to be able to understand and elaborate concepts in the social studies learning process. By understanding the concepts taught through mind mapping media, students can master the material of social studies learning subjects. It will have an impact on improving student learning outcomes. Mind mapping can be made by the educator according to the conditions and material to be taught. Lack of learning media for teaching and learning activities in schools need to find solutions to solve them. Mind 
mapping learning media is a learning media that utilizes student brain as a center to obtain information that is being studied.

This learning media guides students to develop their thoughts on the material they have learned, so that it is easy to learn and remember. Mind Mapping learning media relies on graphic techniques that are very simple but very powerful to summarize a material that is universal and becomes a map that contains material that is very easy to remember. Buzan in Wayan Darmayoya [11] states that mind mapping can be compared to city maps, where the mind mapping center is similar to the city center. The center of the mind map represents the most important ideas and the main ways that spread from the center represent the main thoughts in our thought process. Secondary paths represent secondary thoughts and so on.

According to Wayan Darmayoya [11], there are several benefits of mind mapping including (1) giving a holistic view of the subject matter or broad area, (2) allowing us to plan routes or make choices and know where we are going and where we are going, (3) collecting large amounts of data somewhere, (4) encouraging problem solving by letting us see the paths of new creative breakthroughs, (5) pleasant to see, read, digest and remember. Based on the description above, the purpose of this study is to find out the use of mind mapping in creating interesting and interactive learning in the social studies learning process at public junior high school no. 1 South Siberut Mentawai, and to find out the obstacles in using mind mapping to create interesting learning and interactive in the social studies learning process at public junior high school No. 1 South Siberut Mentawai.

\section{METHOD}

This research uses qualitative research by using a descriptive approach. The type of qualitative research is to provide an overview of the problems being studied related to mind mapping learning media in social studies subjects. This approach is intended to find out the phenomenon of what is experienced by research subjects. In addition, this study also aims to understand the objects under study specifically by using a systematic way of making observations. Data collection In this study carried out as follows:

According to Jorgensen in [12] observation can be defined based on seven characteristics, namely: special interest in meaning and human interaction based on the perspectives of people in or members of a particular situation or situation, the application of participant roles that demand direct relationship with the informant. This observation is used to observe directly and indirectly about the use of mind mapping learning media in social studies learning at public junior high school No. 1 South Siberut Mentawai.

An interview is a conversation with a specific purpose. The conversation was carried out by two parties, namely the interviewer who asked the question and the interviewee who provided the answer to that question [13]. Interviews are used to hold communication with related parties, including principals, teachers and students in order to obtain an explanation of the use of mind mapping learning media in social studies learning. Data analysis technique is carried out as follows. Data reduction is the activity of summarizing field notes by sorting out the main points relating to research problems, summarizing the field notes is then systematically compiled to provide a sharper picture and facilitate retrieval at any time if data is needed again.

To establish conclusions that are more reasonable and no longer in the form of trial and error conclusions, then verification is carried out throughout the study in line with member check, triangulation and audit trail, thereby ensuring the significance of the results of the study. 
In testing the validity of the data the researcher uses a triangulation technique, that is checking the validity of the data that utilizes something other than the data for checking purposes or as a comparison of the data, and the most widely used triangulation technique is by checking through other sources. According to [13], triangulation is a data validity checking technique that utilizes something else. Outside the data for checking purposes or as a comparison of the data. The most widely used triangulation technique is checking through other sources. Triangulation in this research is done through interviews, direct observation and indirect observation. Indirect observation is intended in the form of observation of some behaviors and events that happened during the learning proses. Data collection techniques used will complement in obtaining primary and secondary data, observation and interviews are used to capture primary data relating to the mind mapping in the learning social studies at public junior high school No. 1 based on the data collected.

Researcher conducted pre-survey to the location to be studied. Researchers came to the location, conducting dialogues with the principal, several teacher representatives, also employees and students. Then the researchers also conducted documentation study and literature to see and record the data needed. The interview with the related informants done by using interview guidelines that have been provided by researchers. Besides that, the researcher conducted the indirect observations about school conditions and work environment. Phase member check, after the data is obtained in the field, either through observation, interviews or documentation studies, the informants are given the opportunity to assess their information data that has been given to researchers. Researcher then completed or revised new data after checking the validity of the data in accordance with the original source.

\section{RESULTS AND DISCUSSION}

Learning media is an alternative that can be used in the learning process so students are able to receive learning information well. Based on the reality in the field, there have been many media used in the learning process at public junior high school No. 1, South Siberut Mentawai. Base on the observation it found that the learning media just a charts media, but this media can't provide good learning results. In addition there are also teachers using Map, but sometimes students do not really understand the explanation given by the teacher so that basic competence and learning objectives can't be achieved properly. Learning outcome that is expected to run effectively and efficiently not achieved. Based on the results of research conducted in the field, the following results are obtained:

The results of the interviews with several social studies teachers and students about the use of mind mapping learning media in social studies subjects in grade VIII Public junior high school No. 1 South Siberut Mentawai shows that learning process more interesting and students do not feel bored in learning. Students feel attracted to see the teacher in providing material explanations using mind mapping media because the material is very concise and usually uses symbols or pictures and colors. The basic competencies and learning objectives can be achieved well by using mind mapping learning media. It is proven by the students' enthusiasm in learning. Students who are usually in learning never pay attention to the lessons that take place but after the teacher uses the media learning mind mapping in the learning process many students are focused on the media used by the teacher. The students feel the learning process is different from usual. The results of interviews with some students show that when the teacher used map and chart in explaining learning material many students did not understand 
teacher's explanation. In addition there are some students who are sleepy and look focused when the learning process takes place. After using mind mapping media students are more focused in following the teaching and learning process carried out by the teacher. The students become active and creative in learning process.

The use of mind mapping learning media also has several obstacles including: 1) innovation in making mind mapping learning media is still very simple, 2) teachers in the schools are not familiar with the use of learning media because so far the learning process is so conventional and only uses available media such as using charts and maps. The use of mind mapping media only takes core material and does not describe broadly all the material. With the use of learning media mind mapping students and teachers can be active and creative in the ongoing learning process.

Media is everything that can convey and channel messages from sources in a planned manner so as to create a conducive learning environment where the recipient can carry out the learning process efficiently and effectively [14]. Based on the media selection procedure [15], that learning objectives are cognitive learning, something that is still unfamiliar to students, does not require the demonstration of feedback movements, does not need stimulation of color and does not need interaction with real objects, then the media right is to use mind mapping media. According to [16] the functions of teaching media include: (1) facilitating learning for students and facilitating teaching for teachers; (2) the teaching of abstract concepts can be taught in the form of a congress; (3) the lesson path is not boring; (4) all the student's senses can be activated; (5) attract more interest, and provide variations in student learning; (6) helps bring the world of theory/concept closer to reality.
According to [17] which mentions some of the advantages of mind mapping learning models, among others: (1) maximizing the brain's work system. In making this mind mapping students not only use the left brain but also use the right hemisphere of the brain that can play with symbols, colors, and images. (2) encouraging creativity, simple and easy to do. This mind mapping gives freedom to students to express their ideas in the form of visualization. (3) Interesting and easy to catch the eye. The use of symbols, images and colors will certainly be fun for students. Fun activities will create a positive atmosphere in learning. Thus, students will be happy to learn material created using mind mapping. (4) Can view large amounts of data easily. Mind mapping is made on a piece of paper. Mind mapping only records important things that make it easier for students to remember and learn something by looking at the relationships that are formed from keywords, colors, and images. By only seeing one sheet of paper, you will gain a lot of knowledge because it is in the form of concise notes.

Mind Mapping Media greatly impacts learning in schools, especially in public junior high school No. 1 South Siberut Mentawai. It will indirectly create an interesting, conducive and interactive learning process so that the learning objectives of social studies.

\section{CONCLUSIONS}

The conclusions in this study are:

The use of mind mapping in the social studies learning process in grade VIII of Public junior high school No. 1 South Siberut Mentawai, is more effective and efficient. Every minimum competencies and learning objectives can be achieved well by using mind mapping learning media. This is evidenced by the enthusiasm of students in following the teaching and learning process. In addition, the material can be conveyed to students well so that the achievement of an active and creative learning process between 
students and teachers so that the material proclaimed in one semester can be completed in a timely manner and the material of VIII grade students of public junior high school No. 1 South Siberut can be mastered by the students well.

Obstacles obtained are: 1) mind mapping innovation is still very simple 2) teachers in schools are not familiar with the use of learning media because so far the learning process is conventional. So that it can be concluded that the use of mind mapping media in the social studies learning process at public junior high school No. 1 South Siberut is very effective and efficient. Achievement of social studies learning objectives can be achieved optimally.

\section{REFERENCES}

[1] Rusman. (2012). Belajar dan Pembelajaran Berbasis Multimedia. Bandung: Alfabeta

[2] Undang-Undang No. 20 Tahun 2003 Tentang Sistem Pendidikan Nasional. Bandung: Fokumedia

[3] Munib Achmad, dkk. (2011). Pengantar Ilmu Pendidikan. Semarang: Unnes Press.

[4] Badan Standar Nasional Pendidikan (BNSP). (2006). Model Pembelajaran IPS Terpadu. Jakarta: Direktorat Jendral Pendidikan Dasar dan Menengah

[5] Nani, Rosdijati. dkk. (2010). Praktik Paikem IPS SD. Jakarta: Erlangga

[6] Azhar, Arsyad. (2013). Media Pembelajaran. Jakarta: Rajawali Pers

[7] Nurdin, Syafruddin dan Adriantoni. (2016). Kurikulum Dan Pembelajaran. Jakarta: Raja Grafindo Persada.
[8] Daryanto, D. (2013). Media Pembelajaran Peranannya Sangat Penting Dalam Mencapai Tujuan Pembelajaran. Yogya karta: Gava Media.

[9] Nurseto, T. (2011). Membuat Media Pembelajaran yang Menarik. Jurnal Ekonomi \& Pendidikan, (1).

[10] Arsyad, Azhar. (2011). Media Pembelajaran. Jakarta: Raja Grafindo Persada.

[11] Wayan Darmayoga, dkk, (2013). Pengaruh Implementasi Metode Mind Mapping Terhadap Hasil Belajar IPS ditinjau dari Minat Siswa Kelas IV SD Sathya Sai Denpasar. e-Journal Program Pascasarjana Universitas Pendidikan Ganesha, 3(3), 88-99, ISSN 2252 -6403

[12] Mulyana. (2018). Metodologi Penelitian Kualitatif Paradigma Baru Ilmu Komunikasi dan Ilmu Sosial Lainnya. Bandung: Remaja Rosdakarya.

[13] Moleong, J., Lexy. (2009). Metode Penelitian Kualitatif. Bandung: PT. Remaja Rosdakaya.

[14] Munadi, Y. (2013). Media Pembelajaran, Sebuah Pendekatan Baru. Jakarta: Referensi (GP Press Group).

[15] Sadiman, ADkk. (2010). Media Pendidikan: Pengertian, Pengembangan, dan Pemanfaatannya. Jakarta: Rajawali Press.

[16] Rusyana, Adun. dkk. (2012). PrinsipPrinsip Pembelajaran Efektif. Jakarta: Trans Madiri Abadi.

[17] Swadarma, Doni. (2013). Penerapan Mind Mapping dalam Kurikulum Pembelajaran. Jakarta: Elex Media Komputindo. 